\title{
Effects of environmental pollutants on the reproduction and welfare of ruminants
}

\author{
S. M. Rhind ${ }^{1 \dagger}$, N. P. Evans ${ }^{2}$, M. Bellingham ${ }^{2}$, R. M. Sharpe ${ }^{3}$, C. Cotinot ${ }^{4}$, B. Mandon-Pepin ${ }^{4}$, \\ B. Loup ${ }^{4}$, K. D. Sinclair ${ }^{5}$, R. G. Lea ${ }^{5}$, P. Pocar ${ }^{6}$, B. Fischer ${ }^{7}$, E. van der Zalm ${ }^{7}$, K. Hart ${ }^{7}$, \\ J.-S. Schmidt ${ }^{7}$, M. R. Amezaga ${ }^{8}$ and P. A. Fowler ${ }^{8}$ \\ ${ }^{1}$ Macaulay Land Use Research Institute, Craigiebuckler, Aberdeen, AB15 8QH, UK; ${ }^{2}$ Division of Cell Sciences, Institute of Comparative Medicine, University of Glasgow \\ Veterinary School, Glasgow G6 1QH, UK; ${ }^{3}$ MRC Human Reproductive Sciences Unit, Queen's Medical Research Institute, University of Edinburgh, 47 Little France Crescent, \\ Edinburgh, EH16 4TJ, UK; ${ }^{4}$ INRA, UMR 1198, Biologie du Developpement et de la Reproduction 78350, Jouy-en-Josas, France; ${ }^{5}$ Schools of Biosciences, and Veterinary \\ Medicine and Sciences, University of Nottingham, Leicestershire, LE12 5RD, UK; ${ }^{6}$ Department of Animal Science, Division of Veterinary Anatomy and Histology, University \\ of Milan, Via Celoria 10, 20133 Milano, Italy; ${ }^{7}$ Department of Anatomy and Cell Biology, University of Halle, Grosse Steinstrasse 52, 06097 Halle, Germany; ${ }^{8}$ Centre for \\ Reproductive Endocrinology \& Medicine, Division of Applied Medicine, Institute of Medical Sciences, University of Aberdeen, Foresterhill, Aberdeen, AB25 2ZD, UK
}

\begin{abstract}
Anthropogenic pollutants comprise a wide range of synthetic organic compounds and heavy metals, which are dispersed throughout the environment, usually at low concentrations. Exposure of ruminants, as for all other animals, is unavoidable and while the levels of exposure to most chemicals are usually too low to induce any physiological effects, combinations of pollutants can act additively or synergistically to perturb multiple physiological systems at all ages but particularly in the developing foetus. In sheep, organs affected by pollutant exposure include the ovary, testis, hypothalamus and pituitary gland and bone. Reported effects of exposure include changes in organ weight and gross structure, histology and gene and protein expression but these changes are not reflected in changes in reproductive performance under the conditions tested. These results illustrate the complexity of the effects of endocrine disrupting compounds on the reproductive axis, which make it difficult to extrapolate between, or even within, species. Effects of pollutant exposure on the thyroid gland, immune, cardiovascular and obesogenic systems have not been shown explicitly, in ruminants, but work on other species suggests that these systems can also be perturbed. It is concluded that exposure to a mixture of anthropogenic pollutants has significant effects on a wide variety of physiological systems, including the reproductive system. Although this physiological insult has not yet been shown to lead to a reduction in ruminant gross performance, there are already reports indicating that anthropogenic pollutant exposure can compromise several physiological systems and may pose a significant threat to both reproductive performance and welfare in the longer term. At present, many potential mechanisms of action for individual chemicals have been identified but knowledge of factors affecting the rate of tissue exposure and of the effects of combinations of chemicals on physiological systems is poor. Nevertheless, both are vital for the identification of risks to animal productivity and welfare.
\end{abstract}

Keywords: pollutants, endocrine disrupting compounds, reproduction, ruminants

\section{Implications}

Environmental pollutants include a wide range of chemicals, mostly man-made, which are present in products that are used on a daily basis, such as detergents, pesticides and adhesives or derived from the combustion of hydrocarbon fuels. Although concentrations of these chemicals in the environment are generally low and, as such, may not induce adverse effects when acting in isolation, combinations of these chemicals can interfere, subtly, with physiological

${ }^{\dagger}$ E-mail: s.rhind@macaulay.ac.uk systems and therefore the capacity of ruminants and other animals to reproduce, rear offspring or fight disease. Thus, both the viability of populations and the health and welfare of individuals could be compromised by exposure to environmental levels of pollutants.

\section{Introduction}

Historically, ruminant animals production systems were of relatively low intensity; the inputs of energy, food and fertiliser were small and outputs of meat, milk and by-products 
Rhind et al.

were low. Accordingly, fertiliser inputs comprised, primarily, animal and human manure with more unusual products such as seaweed being used only where available. Significant accumulation of pollutants in soils, and potential exposure of animals to elevated concentrations of pollutants was rare and occurred only in certain highly specialised circumstances, for example, where soils were repeatedly fertilised, with ash and bird carcases (Meharg et al., 2006). On the other hand, the potential for pollutant exposure in modern production systems is greatly increased, for several reasons.

First, modern animal production systems involve the widespread use of pesticides and herbicides and traditional organic fertiliser has been replaced to a significant extent with synthetic nitrate fertilisers. However, the economical and environmental costs of inorganic fertiliser production, together with anthropogenic waste generation, have led, in many countries, to a return to the use of processed sewage sludge instead (Commission of the European Communities, 1994; Swanson et al., 2004). The chemical profile of sludge (Smith, 1995) reflects the mix of thousands of different environmental chemicals to which we are exposed, and its use gives rise to potentially increased exposure to, and bioaccumulation of, chemicals. Other potentially polluted materials such as composted green waste, derived from domestic and municipal sources are also being applied to land. Thus, domestic ruminants may be exposed to concentrations of pollutants that are higher than those occurring 'naturally' in the environment, either through the application of chemicals or because they are exposed to modern waste through recycling of waste to land. However, at this time, it is logistically impossible to characterise the magnitude of potential exposure owing to the complexity of the mixture and the high cost of analysis.

Second, while aerial input of pollutants to the environment as a result of human actions would originally have been relatively trivial, comprising small amounts of potentially toxic metals (PTMs) derived from the smelting of ores (Hong et al., 1996) and polycyclic aromatic hydrocarbons (PAHs) as a result of natural and man-made fires (Bostrom et al., 2002; Yunker et al., 2002), in recent decades aerial inputs have increased enormously. Thousands of new, partially volatile, organic chemicals manufactured for a multitude of industrial, agricultural and domestic purposes are being released into the environment. Occasionally, air pollution has been sufficiently severe to cause damage to plants (e.g. acid rain) but effects on animals, and ruminants in particular, have seldom been proven, although often suspected (Kelly, 1995).

\section{Environmental pollutants - what are they and from where do they originate?}

Most, but not all, pollutant types are derived from human activities. From around the time of the Second World War, the nature of the pollutant burden within the environment, its distribution and effects have changed significantly, largely as a result of human activities and inventions. As indicated above, while PTMs have been used for thousands of years, their use has increased enormously and so they have become ubiquitous in the environment and now appear at low concentrations in soils and at higher concentrations in products such as sewage sludge (Smith, 1995). The potential for lowenvironmental concentrations of metals to perturb animal physiology is now being recognised (Spurgeon et al., 1994).

Nitrates are another category of inorganic pollutant that can interfere with animal physiology and in particular with reproductive function; specifically, they have been implicated in altered thyroid function and the disruption of gonadal steroidogenesis (Guillette and Edwards, 2005; Edwards et al., 2006). Thus, their presence in drinking water is of concern to animal (and human) health and productivity.

Human activity and industrialisation have resulted in an increase in the manufacture, use and release into the environment, of a wide variety of organic substances (Table 1). Although not designed to be physiologically active, many of these can bind to steroidal and other cellular receptors or otherwise interfere with endocrine signalling or enzyme systems and thus affect physiological processes in species as diverse as bacteria (Fox, 2004) and mammals (Toppari et al., 1996; Sweeney et al., 2000). Environmental concentrations of these pollutants are seldom high enough to exert toxic effects, in the conventional sense, being similar to background levels (Rhind, 2009), but through subtle effects on physiological systems they can interfere with normal function.

Table 1 Some classes of organic pollutant and their sources or route of entry to the environment

\begin{tabular}{lll}
\hline \hline Chemical class & \multicolumn{1}{c}{ Origin } & Reference \\
\hline PAHs & Incomplete combustion & Yunker et al. (2002) \\
PCB & Adhesives; electrical transformers & Safe (1990) \\
PBDE & Fire retardants electrical equipment and textiles & Eriksson et al. (2001) \\
Phthalates & Plasticizing agent in plastics & Brooke et al. (1991) \\
Alkyl phenol & Paints, cosmetics, etc. & Ahel et al. (1994) \\
Bisphenol A & Food tins; dental composites & Brotons et al. (1995) \\
Dioxins & Paper bleaching; foundries & Skene et al. (1989) \\
Organochlorine pesticides (dieldrin, vinclozolin and kepone) & Agriculture & IEH (1999) \\
Dyes (aniline and benzidine) & Textile industry & IEH (1999) \\
Synthetic hormones (ethynyloestradiol) & Contraceptive pills & IEH (1999) \\
Pharmaceuticals (Prozac) & Human use & Heltsley et al. (2006) \\
\hline \hline
\end{tabular}

$\mathrm{PAH}=$ polycyclic aromatic hydrocarbons; $\mathrm{PCB}=$ polychlorinated biphenyls; $\mathrm{PBDE}=$ polybrominated diphenyl ethers. 
Chemicals that induce effects by perturbing endocrine systems or mimicking endocrine mediators are collectively described as endocrine disrupting compounds (EDCs). Although pollutants can be very different, chemically and mechanistically, for the purpose of this review, it is appropriate to consider all of these organic and inorganic pollutant classes together and to loosely define them as EDCs because all are known to have disruptive capabilities and they have the potential to interact, additively (Bemis and Seegal, 1999).

\section{How do these pollutants affect ruminants?}

Investigations of the effects of EDC exposure on animals have frequently involved the application of pharmacological doses of individual pollutants to laboratory rodents (to elucidate effects and mechanisms of action and to identify risks associated with exposure to individual chemicals) and less controlled studies of wild animals in which effects had been observed following known pollution incidents (Colborn et al., 1993; Institute for Environment and Health (IEH), 1999). Such studies have identified several characteristics of EDCs that make them biologically significant in relation to all animals, including domestic ruminants. They (i) are highly persistent - for example, many EDCs, including PAHs, polychlorinated biphenyls (PCBs) and polybrominated diphenyl ethers (PBDEs), have half lives of about 10 years or more (Smith, 1995) or in the case of heavy metals are never degraded, (ii) are ubiquitous, that is, although production and use can be localised, EDCs are distributed throughout the environment, (iii) frequently accumulate in animal tissue because they are hydrophobic and lipophilic (Nimrod and Benson, 1996), (iv) exert effects on physiological systems at very low concentrations, orders of magnitude lower than those known to have acute toxic effects (Brevini et al., 2005; Fowler et al., 2007a), (v) have unpredictable effects as they can act additively or synergistically (Payne et al., 2000; Rajapakse et al., 2002; Crofton et al., 2005; Hauser et al., 2005), depending on circumstances; mixtures of compounds can induce biological responses, even when each chemical is present at concentrations too low to induce a biological response by itself (Rajapakse et al., 2002; Kortenkamp, 2007) and (vi) can induce changes in organ structure or function in subsequent, unexposed, generations (Bøgh et al., 2001; Anway and Skinner, 2006; Edwards and Myers, 2007; Steinberg et al., 2008).

Collectively, these properties mean that low-level exposure to pollutants has the potential to affect ruminant productivity and, for example, through changes in the immune system, health and welfare. However, the magnitude of the responses, which is likely to depend on many factors, including the rate, timing and duration of exposure, is ill defined and poorly understood for all animal species.

\section{Patterns of exposure and tissue concentrations}

Ruminants, like other terrestrial species, can be exposed to pollutants, at least theoretically, through ingestion of food and water, through inhalation and by absorption through the skin. It is widely accepted that the primary route of exposure in such species is via the diet (Fries, 1995; Norstrom, 2002) but the significance of other routes of exposure has not been extensively investigated and they may yet prove to be important. Exposure of target organs also depends on the chemical class and associated properties, the age and stage of development of the exposed animal (i.e. foetal, neonatal and adult), the rate of pollutant uptake and rates of subsequent degradation, excretion and/or metabolism (Meador et al., 2008; Rhind, 2008). None of these determinants has been well characterised in ruminants, or indeed for any species, or for any of the classes of EDCs. However, as exposure rates are normally very low and as the health and productivity of the majority of ruminant populations, like that of humans, appears to be unaltered by such levels of exposure, at least superficially, it might be concluded that the environment is almost always entirely benign.

In certain production systems, ruminants can be exposed to slightly higher levels of thousands of different pollutants, relative to those seen in the wider environment, for example when animals are grazed on pastures fertilised with sewage sludge (Rhind, 2005) or drink water contaminated with sewage (Meijer et al., 1999). The practice of recycling human waste is ancient and 'night soil' was collected and returned to land both before and after industrialisation. Processed sewage sludge, as generated in the 21st century, however, is a very different product to that, which has been used as fertiliser in the past as it contains variable combinations of anthropogenic pollutants including organic pollutants and PTMs from domestic, agricultural and industrial sources, at much higher concentrations than those found in the rest of the natural environment (Smith, 1995). However, the actual pattern of exposure to individual pollutants is unknown because it would require analysis of thousands of different chemicals. Rates of tissue accumulation of selected chemicals, and associated effects on the physiology of grazing animals on pastures fertilised with sewage sludge have been addressed both theoretically and in practice. Theoretical estimation of tissue accumulation of individual pollutants would suggest that increases in tissue levels would be small and of no physiological consequence (Wild and Jones, 1992; Duarte-Davidson and Jones, 1996). These conclusions have been largely supported by empirical studies that involved exposure of animals to sewage sludge or to specific compounds (Fries and Marrow, 1977; Fries et al., 1978; Fries, 1996; Rhind et al., 2005a, 2005b, 2007 and 2009). None of these studies reported the patterns of reproductive performance associated with exposure to pollutants but related studies, discussed below, have shown that even such small increases in tissue concentrations of the pollutants measured, following sludge exposure, are associated with physiological changes. It should be noted that a relatively limited range of chemical types has been measured in tissue and it cannot be assumed that those measured are the ones responsible for inducing the observed effects; at best, the reported values represent an index of the total pollutant 'insult', which is likely to include several thousand chemicals. 


\section{Effects on animal physiology}

The fundamental mechanisms of action of pollutants have been investigated and reviewed previously (Sikka and Naz, 1999; Rhind, 2002). The majority of experiments have been based on laboratory rodents and studies in ruminants are relatively rare; a small number of studies, mostly in sheep, have addressed the physiological effects of EDC exposure, using the classical model whereby relatively high concentrations of selected pollutants are administered for short periods of time (Beard et al., 1999; Sweeney et al., 2000; Wright et al., 2002). However, additional results are now emerging from investigation of the effects of prolonged, low-level exposure to EDC mixtures in sheep that have been maintained on sewage sludge-treated pastures (Erhard and Rhind, 2004; Paul et al., 2005; Fowler et al., 2008; Bellingham et al., 2009; Lind et al., 2009). In these studies, the concentrations of chemicals to which animals were exposed, and the specific mixture of chemicals involved, were not comprehensively defined because this would have been logistically impossible. However, effects of exposure were demonstrated by comparing animals reared on sludgetreated pastures with others reared on comparable pastures treated with inorganic fertiliser, which contains minimal amounts of pollutants.

The majority of reported ruminant trials have concentrated on the effects of EDC exposure on the reproductive axis and the results can be classed according to organ/function.

\section{Hypothalamic-pituitary axis}

The endogenous activity of the gonads is driven by the actions of the hypothalamus and pituitary gland, both of which are steroid-sensitive and, thus, potential targets for EDCs. Studies in sheep and goats have reported significant effects of exposure to chemicals with known endocrine disrupting effects, including octylphenol (Sweeney et al., 2000; Wright et al., 2002), bisphenol A (Evans et al., 2004; Savabieasfahani et al., 2006), methoxyclor (Savabieasfahani et al., 2006), PCB153 (Lyche et al., 2004; Oskam et al., 2005) and valporate (Krogenaes et al., 2008), on the hypothalmicpituitary (HP) gland axis. The majority of these studies have investigated the effects of EDCs on the HP axis during development, that is, during gestation and/or lactation, the most sensitive 'windows', when the endocrine system can be permanently altered (IPCS, 2002). Comparison of the results obtained in these studies show that although the chemicals applied and/or the purported mechanisms of action were similar, the observed effects were often chemical and species specific. For example, the timing of puberty, which reflects activation of the HP axis, was advanced in female lambs exposed to octylphenol (Wright et al., 2002), delayed in both male (Oskam et al., 2005) and female (Lyche et al., 2004) goats exposed to PCB153, and remained unchanged in male (Oskam et al., 2005) and female (Lyche et al., 2004) goats exposed to PCB126, during development. These results illustrate the complexity of the effects of EDCs on the HP axis and the difficulty of extrapolating between, or even within, species.

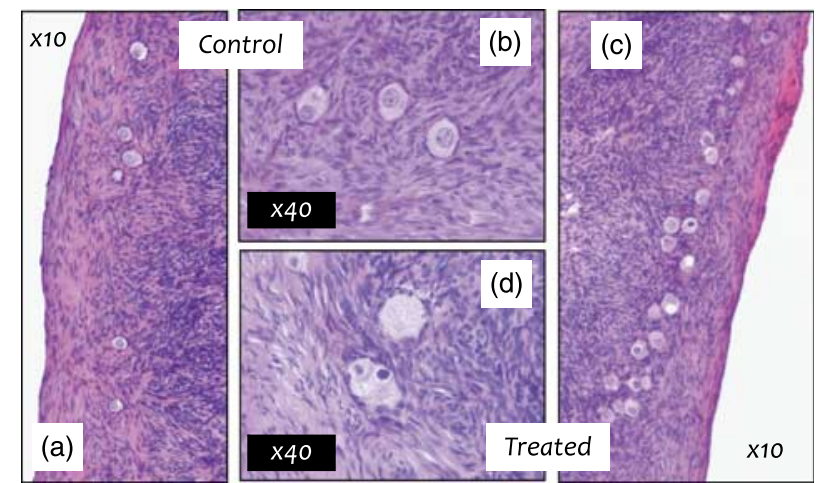

Figure 1 Ovaries (hematoxylin-stained sections) of 18-month-old ewes exposed from conception to control inorganic fertiliser $(a, b)$ or sewage sludge fertiliser $(c, d)$; panels $a$ and $c \times 10, b$ and $d \times 40$ objective magnification. Treated ovaries have a higher proportion of unhealthy primordial and activating primordial follicles. Unhealthy follicles include follicles with intense nuclear staining (c, d), vacuoles (c) and clusters of two or more oocytes, which often share a common layer of granulosa cells $(c, d)$.

In line with the hypothesis that exposure, during critical windows of development can be more disruptive to physiological systems, the results of studies that exposed sheep to the same dose of octylphenol, at different development stages, indicated different physiological consequences. Exposure to pharmacological doses during development (in utero and early post natal period), the period during which HP axis differentiation and sexual dimorphism occurs (Rhind et al., 2001; Robinson, 2006), was found to be potentially more detrimental than later exposure and was seen to induce effects on reproductive function/physiology which were manifested only in later life. For example, gestational exposure to octylphenol at $1 \mathrm{mg} / \mathrm{kg}$ per day for 2 weeks resulted in reduced foetal FSH secretion, which compromised testis development (Sweeney et al., 2000) and lactational exposure was associated with altered semen quality (Sweeney et al., 2007). Similarly, octylphenol exposure of female lambs, in utero, altered FSH secretion during the late follicular phase, and changed the timing of puberty (Wright et al., 2002). However, exposure to similar doses of octylphenol during the pre-pubertal period had no significant effect on either LH or FSH secretion in female lambs (Evans et al., 2004).

Bisphenol A exposure, also at pharmacological doses ( $5 \mathrm{mg} / \mathrm{kg}$ per day for 2 months) has also been shown to suppress LH secretion in female sheep either when exposure occurs during development (Savabieasfahani et al., 2006) or during the pre-pubertal period (Evans et al., 2004). Although it was not possible to determine the exact nature and location of action in these studies, Katoh et al. (2004) showed that bisphenol exposure affected growth hormone through an effect exerted at the level of the pituitary gonadotrophes, whereas other studies such as those by Wright et al. (2002) with octylphenol, and Lyche et al. (2004) with PCB153, have indicated that EDC exposure can have effects at the level of the hypothalamus as puberty is driven by maturational changes in the hypothalamus and the timing of puberty was affected in both studies. 
A criticism of the above studies that have investigated the effects of EDCs on the HP axis is that they addressed effects of exposure to pharmacological doses of single chemicals, at concentrations hundreds or thousands of times higher than the levels present in the environment, where effects are likely to be exerted through the actions of many chemicals, at low concentrations, in combination. Studies using the sewage sludge model described earlier provide a means to address this real world exposure. Preliminary results indicate that sludge exposure alters the population of gonadotrophes in the pituitary glands of adult ewes that had been maintained on these pastures and changes the phenotype of pituitary cell populations. Changes in the activity of a number of neurotransmitter systems within the hypothalamus have been reported (Bellingham et al., 2009). Given the fundamental importance of the HP axis in the regulation of normal gonadal function, alterations to this system by EDCs, may have deleterious consequences for ovarian or testicular function and thus reproductive function and fertility.

\section{Testis}

As for the HP axis, most studies of EDC effects have involved laboratory animals and employed levels of chemical exposure that are probably not environmentally relevant (Hotchkiss et al., 2008). More recently, several well-designed studies have investigated the effect of mixtures of EDCs on the developing rodent testis and its functions, and have shown that combinations of, for example, anti-androgenic $E D C$, exert major effects at doses at which the individual EDCs have no significant effect (Christiansen et al., 2008; Rider et al., 2009). Such observations indicate that it is likely that in domestic animals, exposure to the thousands of EDCs in the environment will exert effects on the developing testis, although the large numbers of chemicals involved and the potential complexities of their interactions make it difficult to predict the incidence or severity of such effects. Nevertheless, the high incidence of reproductive abnormalities in human males at birth (cryptorchidism and hypospadias) and in adulthood (e.g. low-sperm counts), together with the evidence of temporal changes in incidence of these disorders, especially of falling/low-sperm counts (Swan et al., 2000), is at least consistent with environmental impacts (Skakkebaek et al., 2001; Sharpe and Skakkebaek, 2003).

The issue of falling sperm counts in human males remains controversial, largely because of difficulties in proving/disproving that it is happening and of identifying potential causes (Swan et al., 2000). One argument against sperm counts having fallen is the absence of evidence of any similar decline in domestic ruminants, over the same time period; it is assumed that their exposures should be broadly similar to that of humans (Setchell, 1997). However, this comparison is invalid for two reasons. First, and most important, domestic ruminants store sperm and are thus able to maintain a high and uniform sperm count over many frequent ejaculations, whereas humans do not store sperm and therefore sperm counts are greatly affected by ejaculatory frequency (Sharpe, 1994). Consequently, sperm counts in the ejaculates of domestic ruminants do not provide an accurate insight into the level of sperm production, whereas in humans it does (Sharpe, 1994; Sharpe and Skakkebaek, 2003). Second, domestic animals are constantly selected for high fertility/ sperm production and normal husbandry practice would have resulted in the culling of less fertile animals within the timescale that sperm counts have 'fallen', whereas reproductive technologies act to perpetuate and potentially exacerbate defects in human sperm production.

The rodent EDC mixture studies referred to above have not so far addressed effects on sperm counts/sperm production, although the reported adverse effects on foetal testis development including suppression of androgen production/ action would be expected to reduce Sertoli cell proliferation in foetal life (Scott et al., 2007 and 2008). Similar results have also been found in the foetal sheep after pregnant ewes were reared on pasture fertilised with sewage sludge (Paul et al., 2005); specifically, foetal blood testosterone levels were reduced alongside of reductions in Leydig, Sertoli and germ cell numbers. Although these effects were considerable, they did not allow dissection of mechanisms and of cause and effect relationships; on the basis of rodent studies, it would be expected that reduced intra-testicular testosterone concentrations during development would result in reduced Sertoli cell number in the adult (Scott et al., 2007). However, studies in the rat have also shown that even when Sertoli cell number is reduced at birth by $40 \%$ to $50 \%$, compensation occurs rapidly after birth so that normal Sertoli cell numbers are restored by puberty and maintained into adulthood (Hutchison et al., 2008; Scott et al., 2008). However, this recovery occurred following cessation of the causal treatment (in this instance, dibutyl phthalate) and so it could be argued that continued EDC exposure through foetal and postnatal life, which is more akin to 'real world' exposures, might interfere with compensatory Sertoli cell proliferation; this possibility remains to be tested.

Rat studies have led to the identification of 'a male programming window' (Welsh et al., 2008), during which androgens (produced by the foetal testis) act to programme later development of the reproductive tract and genitalia. Deficient androgen action during this time window leads to permanent reductions in size of the penis, prostate and testis and increased risk of malformations such as hypospadias and cryptorchidism (Welsh et al., 2008). Exactly, the same time window applies to programming of the male-female difference in anogenital distance and so the latter, at any age after birth, can provide an index of overall androgen exposure/action within the male programming window (Scott et al., 2008; Welsh et al., 2008). A similar time window applies to domestic ruminants, the best characterised being in the sheep (Wood and Foster, 1998), and is thought, by analogy to the rat and human, to start when testosterone production by the foetal testis first commences (Welsh et al., 2008). With regard to the effects of EDC exposure, the most important implication of these findings is that only exposure within the male programming window is likely to affect androgen-dependent reproductive development. 
Rhind et al.

Table 2 Ovarian follicle and oocyte disruption by EDC - mechanisms and effects

\begin{tabular}{|c|c|c|}
\hline Agent & Effect & Reference \\
\hline BPA & Abnormal chromosome number; embryo defects & Hunt et al. (2003) \\
\hline BPA/Zearalenone & Increased cycle length & Nikaido et al. (2004) \\
\hline Zearalenone & Reduced ovulation rate & Hussein and Brasel (2001) \\
\hline Zearalenone & $\begin{array}{l}\text { Reduced meiotic maturation of bovine oocytes and increased } \\
\text { chromatin abnormalities }\end{array}$ & Minervini et al. (2001) \\
\hline DES/EE2 & Polyovular follicles; reduced fertilisation & Kirigaya et al. (2006) \\
\hline Androgenic EDCs & Accelerated follicle development & Forsdike et al. (2007) \\
\hline PCB & Disrupted oocyte maturation and embryo development & Pocar et al. (2001a) \\
\hline PCB & Increased polyspermy & Pocar et al. (2001b) \\
\hline PCB & Variable translational regulation within oocyte & Pocar et al. (2001b) \\
\hline PCB & Increased apoptosis in cumulus cells & Pocar et al. (2005b) \\
\hline MEHP & Reduced meiotic maturation of bovine oocytes & Anas et al. (2003) \\
\hline Octylphenol & Perturbed bovine oocyte maturation & Pocar et al. (2003) \\
\hline Mixture & Reduced oocyte density in fetuses & Fowler et al. (2008) \\
\hline Mixture & Reduced follicle health in adults & Amezaga et al. (2009) \\
\hline Mixture & Altered expression of multiple genes & Mandon-Pepin et al. (2009) \\
\hline
\end{tabular}

$\mathrm{EDC}=$ endocrine disrupting compound; $\mathrm{BPA}=$ bisphenol $\mathrm{A} ; \mathrm{DES}=$ diethylstilbestrol; $\mathrm{EE2}=$ ethinyl estradiol; $\mathrm{PCB}=$ polychlorinated biphenyls; MEHP = mono ethylhexyl phthalate.

However, development of the normally formed penis (Welsh et al., 2008) and the increase in Sertoli cell number/determination of adult testis size (Scott et al., 2008) also depend upon androgen action after the male programming window and therefore may be susceptible to EDC effects for a greater period.

\section{Ovary}

Ovarian follicle formation in ruminants occurs during foetal life (Rüsse, 1983) and involves the assembly of meiotically arrested oocytes and somatic pre-granulosa cells into primordial follicles (Hirshfield, 1991). EDCs could, potentially, perturb the function of each of the cell types involved. Female germ cells begin meiosis during early development, and EDC-exposure at this time can potentially reduce a female's lifetime reserve of oocytes, which cannot be renewed, unlike males in which continuous spermatogenesis may quench transient EDC effects. On the other hand oogonia may be less sensitive than male germ cells to some gonotoxic insults (e.g. Guerquin et al., 2009).

The developmental stage at which damage occurs determines the impact that exposure to chemicals will have on reproduction (Hoyer, 2005; Uzumcu and Zachow, 2007). Chemicals selectively damaging large growing or antral follicles only temporarily interrupt reproductive function, unlike when damage to the primordial follicle population occurs, because these are replaced by recruitment from the primordial follicle pool. Two key developmental processes occur subsequent to oocyte meiotic arrest: (i) primordial follicle assembly (at 75-day gestation in sheep: Sawyer et al., 2002) and (ii) primordial follicle recruitment. Both are coordinated by paracrine and autocrine growth factors and occur in the later stages of ruminant gestation (McNatty et al., 1999). Primordial follicles are then activated and recruited into the growing cohort of primary follicles, a vital determinant of reproductive life span (Skinner, 2005). Thus it is possible to investigate the effects of EDC exposure in relation to the known developmental changes that occur during maturation of the oocycte, its release and fertilisation.

As multiple ovarian systems are sensitive to EDCs, associated effects are diverse and dependent on the specific chemical involved (Table 2). As for other organs, exposure to environmental concentrations of pollutant mixtures has been shown to perturb ovarian development in the sheep (Fowler et al., 2008; Mandon-Pepin et al., 2009) and follicle health in the adult offspring (Figure 1; Amezaga et al., 2009). Disruption of the first stages of gametogenesis and gonadal differentiation, in utero, ultimately control reproductive viability in mature offspring and can have transgenerational consequences (Anway and Skinner, 2006).

With regard to future investigations of these effects, it should be noted that much of the literature concerning reproductive effects of EDCs is based on rodent models but ruminants exhibit significant differences in physiology compared with, say, laboratory rodents such as mice; for example, steroidogenesis occurs in ruminants during foetal, not postnatal, ovarian development. Thus, the use of the rodent model alone to understand risks posed to domestic ruminants is unwise.

\section{Oocyte maturation and early embryo development}

During maturation, the oocyte and early embryo are particularly susceptible to pollutants, even at the background doses to which they might be exposed, in vivo, when their mothers are not exposed to elevated environmental levels of pollutants (Pocar et al., 2001a and 2001b). For example, incubation with PCBs $(0.0001$ to $1 \mu \mathrm{g} / \mathrm{ml}$ of a mixture of PCBs (Aroclor); exposed for 24 to $48 \mathrm{~h}$ ) significantly reduced the percentage of bovine oocytes reaching metaphase II, and lower doses that do not impair meiotic processes reduced 
fertilisation rates and embryonic development (Pocar et al., $2001 \mathrm{a}$ and 2001b). Some of the underlying mechanisms responsible for this, and similar effects, have been identified (Table 2) but many potential mechanisms remain to be investigated.

The processes of endometrial transformation, and development and implantation of the embryo depend on an exchange of hormonal signals between the embryo and mother. During early embryo development and the implantation window, specific amounts of oestradiol (E2) and progesterone $(P)$ are required for endometrial maintenance and chorionic gonadotropin for maintenance of hormone production by the corpus luteum (Makrigiannakis et al., 2006). These vital endocrine dialogues can be disturbed by EDCs. In addition to indirect effects of EDCs on embryo development, exerted via changes in hormone profiles, direct embryotoxic effects are possible through actions of EDCs on hormone receptors (Agras et al., 2007; Davey et al., 2007). It has been shown that the hormone receptor expression in blastocysts differs between embryoblast and trophoblast, which represent different cell lineages, and this results in different developmental impacts (Navarrete Santos et al., 2004a, 2004b and 2008). Along with steroid hormone receptors, many of the effects of EDCs on pre-implantation embryos, and on implantation, are mediated through the aryl hydrocarbon receptor (AhR) and peroxisome proliferatoractivated receptor (PPAR) signalling pathways. The AhR, a binding partner of dioxins and coplanar PCBs (McMillan and Bradfield, 2007), is essential for fertility, being involved in folliculogenesis, oestrogen biosynthesis and signalling, progesterone biosynthesis and corpus luteum function (e.g. Pocar et al., 2004, 2005a and 2005b, Li et al., 2006; Barnett et al., 2007, Ohtake et al., 2009). It may be necessary, also, for normal development of the pre-implantation embryo (Clausen et al., 2005) and embryo-maternal signalling during implantation. Both indirect and direct EDC effects were observed at environmentally relevant concentrations with exposure durations between $4 \mathrm{~h}$ and 7 days (short-term) or 6 to 12 weeks (long-term).

Pre-implantation exposure to EDCs of a variety of classes, at environmentally relevant concentrations, can perturb the reproductive and implantation systems of early embryos through some of the above mechanisms (Table 3). Effects include perturbation of energy metabolism (Tonack et al., 2007) and downregulation of relevant genes (Hanlon et al., 2005). As PPAR signalling is disrupted by EDCs (Huang, 2008; Nakanishi, 2008) and affects AhR expression (Hanlon et al., 2003; Lovekamp-Swan and Davis, 2003; Villard et al., 2007), it directly links metabolic and EDC pathways with pollutants.

In summary, embryo implantation is highly vulnerable to endocrine disruption, as EDCs, (plasticiser, PAHs, PCBs, PDBEs, dioxins, pesticides, organotins and heavy metals) at concentrations as low as $10 \mathrm{nM}$ or $2 \mathrm{ng} / \mathrm{kg}$ and for an exposure period as short as $4 \mathrm{~h}$, can interfere with the actions of many hormones and receptors essential for pre- and peri-implantation development of the embryo and endometrium.

\section{Effects on other aspects of animal health and welfare} Although direct effects on components of the reproductive system are often among the most noticeable adverse effects of pollutants, animal performance and welfare can also be compromised by sub-optimal function in other physiological systems. Milk production and associated success in rearing offspring are critical to healthy populations. Rodent studies have shown that mammary development, differentiation and gene expression can be perturbed by exposure to organic pollutants before or around puberty (Fenton, 2006; Moral et al., 2008) and during pregnancy (Fenton, 2006), potentially compromising neonatal nutrition and survival. Similarly, studies of the mammary tissue of sheep exposed to sewage sludge (Fowler et al., 2007b) demonstrated changes in tissue structure and associated protein expression.

Table 3 Early embryo disruption by EDC - mechanisms and effects

\begin{tabular}{lll}
\hline \hline Agent & \multicolumn{1}{c}{ Effect } & \multicolumn{1}{c}{ Reference } \\
\hline Dioxin (TCDD) & Damaged embryonic cells/mitotic disorders & Hutt et al. (2008) \\
& Wasting syndrome/perturbed energy metabolism & Swedenborg et al. (2009) \\
PAHs & Embryo loss (caspase 3/bax-mediated cell death) & Det al. (2006) \\
KCBs & Disturbed energy metabolism & Clausen et al. (2005) \\
& Altered expression of implantation relevant genes & Brevini et al. (2004) \\
& Inhibition of blastocyst development & Inoue et al. (2004) \\
Nitrate/nitrite & Reduced progesterone production and reproductive success & Nandi et al. (2010) \\
Heavy metals & Reduced viability, morphological abnormalities, inhibited cell & \\
& division and blastocyst development & Thompson and Bannigan (2008) \\
& Suppressed steroid synthesis, delayed implantation, early & Greenlee et al. (2005) \\
Pesticides (various) & embryo loss and apoptosis & Wójtowicz et al. (2007) \\
& Blastomere apoptosis & Ema et al. (2007) \\
& Perturbed hormone production & Amstislavsky et al. (2006) \\
& Reduced maternal progesterone; implantation failure & Hausburg et al. (2005) \\
\hline
\end{tabular}

$\overline{E D C}=$ endocrine disrupting compound; $\mathrm{TCDD}=$ 2,3,7,8-Tetrachlorodibenzo-p-dioxin; $\mathrm{PAH}=$ polycyclic aromatic hydrocarbons; $\mathrm{PCB}=$ polychlorinated biphenyls. 
Rhind et al.

The capacity of environmental pollutants to adversely affect the immune system and the importance of exposure during foetal development, are well known from studies of species exposed to heavy pollutant burdens (Martineau et al., 1988; De Swart et al., 1995; Dietert and Piepenbrink, 2006). The complexity and individual variability of the immune response makes it difficult to detect when the suppression is modest, as is likely to be the case in ruminants, but it remains highly likely that EDC exposure is having adverse effects on immune function in this taxon as well.

EDC exposure can affect thyroid function and therefore metabolism; for example, EDCs have been shown to inhibit the expression of nuclear thyroid hormone receptors or perturb the hypothalamic-pituitary-thyroid axis (Jekat et al., 1994; Hansen, 1998; Sugiyama et al., 2005). In addition, PCBs acting via AhRs, can induce multiple histological and physiological changes within the gland, affecting thyroid hormone production (Hansen, 1998). As the thyroid gland is involved in the regulation of many fundamental physiological processes, particularly in the developing animal (Erenberg et al., 1974), and in seasonal reproductive transitions (Shi and Barrell, 1992), its disruption could adversely affect animal health, welfare, reproduction and productivity.

Effects of exposure to environmental pollutants on bone structure have been identified previously in both wildlife (Lind et al., 2004a; Lundberg et al., 2008) and domestic species (Lundberg et al., 2006) and recent work involving the sewage sludge paradigm has shown that exposure to a mixture of pollutants at low concentrations can increase mineral content and reduce bone strength, at least in females, (Lind et al., 2009).

Studies of humans also indicate that environmental pollutants can affect adipogenesis (Stahlhut et al., 2007). Experiments involving various species indicate that phthalate exposure can induce insulin resistance and alter receptor activity, glucose transporters and transcription factors (Alonso-Magdalena et al., 2005; Fujiyoshi et al., 2006; Grun et al., 2006). Thus, it seems likely that subtle changes in nutrient partitioning and in feed efficiency will occur in EDCexposed ruminants although they are, as yet, undetected.

Exposure of rats to PCBs increased serum cholesterol concentrations and blood pressure, risk factors for heart disease (Lind et al., 2004b), and studies of humans suggest a relationship between dioxin exposure and risk of cardiovascular disease (Humblet et al., 2008). Theoretically, such subclinical disorders have the potential to compromise ruminant health and welfare, causing small reductions in productivity.

One measure of neuroendocrine development is offspring behaviour. Altered patterns of behaviour have been reported in children exposed to various pollutants during pre-natal and early post-natal development (Vreugdenhil et al., 2002; Lanphear et al., 2005; Korrick and Bellinger, 2007) and in lambs exposed to sewage sludge, via their dams (Erhard and Rhind, 2004). Altered social or sexual behaviour, learning ability or fearfulness all have the potential to reduce animals' capacity to obtain food, breed and compete successfully with others in the flock or herd.
In summary, environmental pollutants can adversely affect diverse physiological systems and processes in many species, including ruminants. These effects are not generally reflected in visible reductions in animal performance but sub-clinical effects may result in subtle reductions in animal performance, with associated economic consequences. Furthermore, such underlying physiological changes may become increasingly important as new chemicals are manufactured or as concentrations of others in the environment are increased. These add to the animal burden but readily observable effects may only become apparent if, or when, a critical level of the 'insult' is reached. For example, human sperm quality and fertility are reportedly declining over time (Nordstrom Joensen et al., 2009) but effects on conception rates may become obvious only when the number of fertile sperm declines to a critical level. The fact that some effects are known to be exerted on the developing foetus and are expressed in the adult animal and, critically, also in subsequent generations (Bøgh et al., 2001), means that exposures now may lead to animal production problems in the future.

\section{Future research needs}

In order to understand risks and effects, the input of pollutants into biological systems has to be defined. However, at present, measures of environmental concentrations are costly, often technically difficult, and generally limited to relatively few of the thousands of chemicals that may be important. Such measurements rarely take account of factors that can affect biological availability such as substrate binding or conversion into different forms with different chemical characteristics and/or biological effects.

Similarly, the processes regulating transfer of pollutants between the environment and the target organs, in animals at each stage of development, must be better characterised. The overall efficiency of this process depends on several components including the rate of ingestion or inhalation and pollutant availability, as determined by the strength of bonds between it and the substrate (food, soil, water and air). Transfer depends, also, on the efficiency of physiological processes such as uptake from the maternal gastrointestinal tract, lungs or skin and, following uptake by the dam, uptake from the maternal circulation via the placenta, rates of foetal metabolism, excretion and absorption into lipid stores (Rhind, 2008). These processes have been quantified for very few species or pollutant classes.

Understanding the effects of pollutants requires knowledge of actions at the cellular and molecular level. Different sets of genes are expressed while others are silenced, in a developmental stage and tissue-specific manner, by the coordinated action of a number of epigenetic mechanisms that involve chemical modifications to both DNA and chromatin (Li, 2002; Morgan et al., 2005). The precedent that EDCs can epigenetically modify at least one of these modifications (i.e. DNA methylation) in the germ line, thereby promoting transgenerational abnormalities including impaired male fertility, has been established in rats exposed to the agricultural 
chemicals vinclozolin and methoxychlor (Anway et al., 2005). Although it remains to be determined if the effects of $E D C s$ in ruminants operate by similarly dysregulating the normal pattern of epigenetic-mediated gene expression, a different 'insult', in the form of clinically relevant reductions in specific micronutrients during the peri-conceptional period, in sheep has been shown to lead to widespread epigenetic alterations to DNA methylation in offspring. Such alterations are associated with obesity, insulin resistance and high blood pressure (Sinclair et al., 2007). Consequently, the focus of future studies on the effects of EDC exposure in ruminants will need to consider such modes of action.

The process of identifying causal relationships between different classes of pollutant and their effects has to be extended using numerous approaches already proven in ruminants. These include measurements of changes in organ structure and/or function (Evans et al., 2004; Paul et al., 2005) and in gene or protein expression (Edwards and Myers, 2007; Fowler et al., 2008). However, current understanding of additive and synergistic effects of EDCs, especially in complex mixtures, is, at best, very limited and so elucidation of these effects will be a critical area of future research. As it is logistically impossible to address every possible combination, it will be appropriate to study combinations with different mechanisms of action in order to better comprehend the effects of mixtures (Kortenkamp, 2007). There is also likely to be a significant role for bioinformatics and computer modelling approaches (Suk et al., 2002). However, such studies may be partially constrained by lack of understanding of mechanisms of action and of data pertaining to the effects of each EDC, individually, let alone when part of a mixture.

The variability associated with each of the multiple processes regulating tissue concentrations of EDCs results in very large individual animal variation in tissue concentrations (Rhind, 2008). Investigation of the relationships between genotype and phenotypic responses might be expected to lead to improved predictability of effects but, owing to the complexity of mixtures and multiple genomic factors it is almost impossible for a single DNA variant site to be consistently associated with a particular trait (Nebert, 2005). This area of work is likely to be of major significance in the future, although frequently unpopular with funding agencies.

Although a number of physiological systems have already been shown to be affected by a wide range of chemicals, it is important to recognise not only that there may be chemicals, which are not yet widely recognised as endocrine disruptors, but also that there may be physiological responses to exposure that are not currently recognised as effects of EDC (Guillette, 2006). Thus, it is important that research into these phenomena is approached with an open mind and receptiveness to previously unidentified risks and mechanisms. The work of the European REACH (Registration, Evaluation and Authorisation of Chemicals) programme is designed to address the issue of chemical use and, by implication, environmental pollutants. Although it will undoubtedly help to identify and control the use of the most persistent, bioaccumulative and toxic chemicals, concerns remain that the legislation may fail to take account of effects of mixtures and of chemicals present at levels deemed to be below the 'no effect level' (Santillo and Johnston, 2006).

\section{Conclusions}

Environmental pollutants can adversely affect animal health and reproductive function, through either direct or indirect effects on numerous organs and systems. However, empirical evidence of the relationships between exposure and physiological effects is scarce, particularly for ruminants, reflecting the fact that levels of exposure to each individual chemical are generally very low and they do not act individually. At this time, effects of environmentally relevant levels of exposure to EDCs are not yet reflected in visibly reduced animal performance. Nevertheless, concerns remain that there may be subtle perturbations of reproductive function and since some of the observed changes in physiological function may be expressed in subsequent generations, even without further exposure to pollutants, there may be even greater cause for concern. Like ruminant productivity, human health is generally considered to be good/improving but, at the same time, the incidence of breast cancer in women in the United Kingdom, a disease considered to be related to $E D C$, is increasing at a rate of $2 \%$ every year (Office for National Statistics, 2008) indicating that some trends in health/performance may only be observed on a population basis rather than an individual basis. It is postulated that comparable insidious effects on ruminants may also be present but until appropriate end points are recognised and measured, such potential threats may remain hidden.

\section{Acknowledgements}

Much of the work reported in this paper, and the preparation of the paper, was funded by the Scottish Government Research and Analysis Directorate, the Welcome Trust (Contact no. 080388/Z/06/Z) and the European Commission Framework 7 Programme (Contract no. 212885).

\section{References}

Agras K, Shiroyanagi Y and Baskin LS 2007. Progesterone receptors in the developing genital tubercle: implications for the endocrine disruptor hypothesis as the etiology of hypospadias. The Journal of Urology 178, 722-727.

Ahel M, Giger W and Schaffner C 1994. Behaviour of alkylphenol polyethoxylate surfactants in the aquatic environment-II. Occurrence and transformation in rivers. Water Research 28, 1143-1152.

Alonso-Magdalena P, Laribi O, Ropero AB, Fuentes E, Ripoli C, Soria B and Nadal A 2005. Low doses of bisphenol $A$ and diethylstilbestrol impair $\mathrm{Ca}^{2+}$ signals in pancreatic $\alpha$-cells through a nonclassical membrane estrogen receptor within intact islets of Langerhans. Environmental Health Perspectives 113, 969-977.

Amezaga MR, Speers CJB, Bellingham M, Evans NP, Mandon-Pepin B, Cotinot C, Sharpe RM, Rhind SM and Fowler PA 2009. Sudden changes in exposure to environmental chemicals perturbs ovarian development. In Proceedings of the Society for Reproduction and Fertility, 7-9 January 2009, Edinburgh, UK, p. 37. Amstislavsky SY, Amstislavskaya TG, Amstislavsky VS, Tibeikina MA, Osipov KV and Eroschenko VP 2006. Reproductive abnormalities in adult male mice following preimplantation exposures to estradiol or pesticide methoxychlor. Reproductive Toxicology 21, 154-159. 
Rhind et al.

Anas MK, Suzuki C, Yoshioka K and Iwamura S 2003. Effect of mono-(2ethylhexyl) phthalate on bovine oocyte maturation in vitro. Reproductive Toxicology 17, 305-310.

Anway MD, Cupp AS, Uzumcu M and Skinner MK 2005. Epigenetic transgenerational actions of endocrine disruptors and male fertility. Science 308, 1466-1469.

Anway MD and Skinner MK 2006. Epigenetic transgenerational actions of endocrine disruptors. Endocrinology 147, S43-S49.

Barnett KR, Tomic D, Gupta RK, Babus JK, Roby KF and Terranova PF 2007. The aryl hydrocarbon receptor is required for normal gonadotropin responsiveness in the mouse ovary. Toxicology and Applied Pharmacology 223, 66-72.

Beard AP, Bartelewski PM, Chandolia RK, Honaramooz A and Rawlings NC 1999. Reproductive and endocrine function in rams exposed to the organochlorine pesticides lindane and pentachlorophenol from conception. Journal of Reproduction and Fertility 115, 303-314.

Bellingham M, Fowler PA, Amezaga MR, Rhind SM, Cotinot C, Mandon-Pepin B, Sharpe RM, Kyle CE and Evans NP 2009. Exposure to environmental endocrine disrupting compounds in sewage sludge: effects on the KiSS-1/GPR54 system in ovine hypothalamus and pituitary gland. Environmental Health Perspectives 117, 1556-1562.

Bemis JC and Seegal RF 1999. Polychlorinated biphenyls and methylmercury act synergistically to reduce rat brain dopamine content in vitro. Environmental Health Perspectives 107, 879-885.

Bøgh IB, Christensen P, Dantzer V, Groot M, Thøfner ICN, Rasmussen RK, Schmidt M and Greve T 2001. Endocrine disrupting compounds: effect of octylphenol on reproduction over three generations. Theriogenology 55, 131-150.

Bostrom CE, Gerde P, Hanberg A, Jernstrom B, Johansson C, Kyrklund T, Rannug $A$, Törnqvist M, Victorin $K$ and Westerholm R 2002. Cancer risk assessment, indicators, and guidelines for polycyclic aromatic hydrocarbons in the ambient air. Environmental Health Perspectives 110(suppl. 3), 451-488.

Brevini TAL, Vassena R, Paffoni A, Francisci C, Fascio U and Gandolfi F 2004. Exposure of pig oocytes to PCBs during in vitro maturation: effects on developmental competence, cytoplasmic remodelling and communications with cumulus cells. European Journal of Histochemistry 48, 347-356.

Brevini TAL, Cillo F, Antonini S and Gandolfi F 2005. Effects of endocrine disrupters on the oocytes and embryos of farm animals. Reproduction in Domestic Animals 40, 291-299.

Brooke DN, Nielsen IR, Dobson S and Howe PD 1991. Environmental hazard assessment: di-(2-ethylhexyl) phthalate. Toxic Substances, Division, Directorate for Air Climate and Toxic Substances Department of the Environment, Watford, England.

Brotons JA, Olea-Serrano MF, Villalobos M, Pedraza V and Olea N 1995. Xenoestrogens released from lacquer coatings in food cans. Environmental Health Perspectives 103, 608-612.

Christiansen S, Scholze M, Axelstad M, Boberg J, Kortenkamp A and Hass U 2008. Combined exposure to anti-androgens causes markedly increased frequencies of hypospadias in the rat. International Journal of Andrology 31, 241-248.

Clausen I, Kietz S and Fischer B 2005. Lineage-specific effects of polychlorinated biphenyls (PCB) on gene expression in the rabbit blastocyst. Reproductive Toxicology 20, 47-56.

Colborn T, Vom Saal AM and Soto AM 1993. Developmental effects of endocrine disrupting chemicals in wildlife and human. Environmental Health Perspectives 101, 378-384.

Commission of the European Communities 1994. Directorate Generale XI, Waste Management - Sewage Sludge, Part I. Survey of Sludge Production, Treatment, Quality and Disposal in the European Union. EU Commission, Brussels, Belgium.

Crofton KM, Craft ES, Hedge JM, Gennings C, Simmons JE, Carchman RA, Carter WH and deVito MJ 2005. Thyroid-hormone-disrupting chemicals: evidence for dose-dependent additivity or synergism. Environmental Health Perspectives $113,1549-1554$.

Davey JC, Bodwell JE, Gosse JA and Hamilton JW 2007. Arsenic as an endocrine disruptor: effects of arsenic on estrogen receptor-mediated gene expression in vivo and in cell culture. Toxicological Sciences 98, 75-86.

De Swart RL, Ross PS, Timmerman HH, Vos HW, Reijnders PJH, Vos JG and Osterhaus ADME 1995. Impaired cellular immune response in harbour seals (Phoca vitulina) feeding on environmentally contaminated herring. Clinical and Experimental Immunology 101, 480-486.
Detmar J, Rabaqlino T, Taniuchi Y, Oh J, Acton BM, Benito A, Nunez G and Juriscova A 2006. Embryonic loss due to exposure to polycyclic aromatic hydrocarbons is mediated by Bax. Apoptosis 11, 1413-1425.

Dietert RR and Piepenbrink S 2006. Perinatal immunotoxicity: why adult exposure assessment fails to predict risk. Environmental Health Perspectives $114,477-483$

Duarte-Davidson R and Jones KC 1996. Screening the environmental fate of organic contaminants in sewage sludge applied to agricultural soils: II the potential for transfers to plants and grazing animals. The Science of the Total Environment 185, 59-70.

Edwards TM, Miller HD and Guillette LJ 2006. Water quality influences reproduction in female mosquitofish (Gambusia holbrooki) from eight Florida springs. Environmental Health Perspectives 114(suppl.), 69-75.

Edwards TM and Myers JP 2007. Environmental exposures and gene regulation in disease etiology. Environmental Health Perspectives 115, 1264-1270.

Ema M, Fujii S, Ikka T, Matsumoto M, Hirose A and Kamata E 2007. Early pregnancy failure induced by dibutyltin dichloride in mice. Environmental Toxicology 22, 44-52.

Erenberg A, Omori K, Menkes JH, Oh W and Fisher DA 1974. Growth and development of the thyroidectomized ovine fetus. Pediatric Research 8, 783-789.

Erhard HW and Rhind SM 2004. Prenatal and postnatal exposure to environmental pollutants in sewage sludge alters emotional reactivity and exploratory behaviour in sheep. The Science of the Total Environment 332, 101-108.

Eriksson P, Jakobsson E and Fredriksson A 2001. Brominated flame retardants: a novel class of developmental neurotoxicants in our environment. Environmental Health Perspectives 109, 903-908.

Evans NP, North T, Dye S and Sweeney T 2004. Differential effects of the endocrine-disrupting compounds bisphenol-A and octylphenol on gonadotrophin secretion, in prepubertal ewe lambs. Domestic Animal Endocrinology 26 61-73.

Fenton SE 2006. Endocrine-disrupting compounds and mammary gland development: early exposure and later life consequences. Endocrinology 147, S18-S24.

Forsdike RA, Hardy K, Bull L, Stark J, Webber LJ, Stubbs S, Robinson JE and Franks S 2007. Disordered follicle development in ovaries of prenatally androgenized ewes. Journal of Endocrinology 192, 421-428.

Fowler PA, Abramovich DR, Haites NE, Cash P, Groome NO, Al-Qahtani A Murray TJ and Lea RG 2007a. Human fetal testis Leydig cell disruption by exposure to the pesticide dieldrin at low concentrations. Human Reproduction 22, 2919-2927.

Fowler PA, Gordon KL, Thow CA, Cash P, Miller DW, Lea RG and Rhind SM 2007b. Exposure to sewage sludge disrupts ewe mammogenesis. In Proceedings of the Society for Reproduction and Fertility, 15-18 April 2007, York, UK p. 75.

Fowler PA, Dorà NJ, McFerran $\mathrm{H}$, Amezaga MR, Miller DW, Lea RG, Cash $\mathrm{P}$, McNeilly AS, Evans NP, Cotinot C, Sharpe RM and Rhind SM 2008. In utero exposure to low doses of environmental pollutants disrupts fetal ovarian development in sheep. Molecular Human Reproduction 14, 269-280.

Fox JE 2004. Chemical communication threatened by endocrine-disrupting compounds. Environmental Health Perspectives 112, 648-653.

Fries GF 1995. A review of the significance of animal food products as potential pathways of human exposures to dioxins. Journal of Animal Science 73, 1639-1650.

Fries GF 1996. Ingestion of sludge applied organic chemicals by animals. The Science of the Total Environment 185, 93-108.

Fries GF and Marrow GS 1977. Distribution of hexachlorobenzene residues in beef steers. Journal of Animal Science 45, 1160-1165.

Fries GF, Cook RM and Prewitt LR 1978. Distribution of polybrominated biphenyl residues in the tissue of environmentally contaminated dairy cows. Journal of Dairy Science 61, 420-425.

Fujiyoshi PT, Michalek JE and Matsumura F 2006. Molecular epidemiologic evidence for diabetogenic effects of dioxin exposure in US air force veterans of the Vietnam War. Environmental Health Perspectives 114, 1677-1683.

Greenlee AR, Ellis TM, Berg RL and Mercieca MD 2005. Pregnancy outcomes for mouse preimplantation embryos exposed in vitro to the estrogenic pesticide o,p'-DDT. Reproductive Toxicology 20, 229-238 
Grun F, Watanabe H, Zamanian Z, Maeda L, Arima K, Cubacha R, Gardiner DM Kanno J, Iguchi T and Blumberg B 2006. Endocrine disrupting organotin compounds are potent inducers of adipogenesis in vertebrates. Molecular Endocrinology 20, 2141-2155.

Guerquin MJ, Duquenne C, Coffigny H, Rouiller-Fabre V, Lambrot R, Bakalska M, Frydman R, Habert R and Livera G 2009. Sex-specific differences in fetal germ cell apoptosis induced by ionizing radiation. Human Reproduction 24, 670-678.

Guillette LJ 2006. Endocrine disrupting compounds - beyond the dogma. Environmental Health Perspectives 114(suppl. 1), 9-12.

Guillette LJ and Edwards T 2005. Is nitrate an ecologically relevant endocrine disruptor in vertebrates? Integrative and Comparative Biology 45, 19-27.

Hanlon PR, Ganem LG, Cho YC, Yamamoto M and Jefcoate CR 2003. AhR- and ERK-dependent pathways function synergistically to mediate 2,3,7,8-tetrachlorodibenzo-p-dioxin suppression of peroxisome proliferator-activated receptorgamma1 expression and subsequent adipocyte differentiation. Toxicology and Applied Pharmacology 189, 11-27.

Hanlon PR, Cimafranca MA, Liu X, Cho YC and Jefcoate CR 2005. Microarray analysis of early adipogenesis in $\mathrm{C} 3 \mathrm{H} 10 \mathrm{~T} 1 / 2$ cells: cooperative inhibitory effects of growth factors and 2,3,7,8-tetrachlorodibenzo-p-dioxin. Toxicology and Applied Pharmacology 207, 39-58.

Hansen L 1998. Stepping backward to improve assessment of PCB congener toxicities. Environmental Health Perspectives 106, 171-189.

Hausburg MA, Dekrey GK, Salmen JJ, Palic MR and Gardiner CS 2005. Effects of paraquat on development of preimplantation embryos in vivo and in vitro. Reproductive Toxicology 20, 239-246.

Hauser R, Williams P, Altshul L and Calafat AM 2005. Evidence of interaction between polychlorinated biphenyls and phthalates in relation to human sperm count. Environmental Health Perspectives 113, 425-430.

Heltsley R, Cope WG, Bringolf R, Eads C and Shea D 2006. Prozac elicits spawning in native freshwater mussels. Poster presented at the 232nd Meeting of the American Chemistry Society. American Chemical Society, Washington, DC.

Hirshfield AN 1991. Development of follicles in the mammalian ovary. International Review of Cytology 124, 43-101.

Hong S, Candelone J-P, Patterson CC and Boutron CF 1996. History of ancient copper smelting pollution during Roman and medieval times recorded in Greenland ice. Science 272, 246-249.

Hotchkiss AK, Rider CV, Blystone CR, Wilson VS, Hartig PC, Ankley GT, Foster $\mathrm{PM}$, Gray CL and Gray LE 2008. Fifteen years after 'Wingspread' environmental endocrine disruptors and human and wildlife health: where are we today and where we need to go. Toxicological Sciences 105, 235-259.

Hoyer PB 2005. Damage to ovarian development and function. Cell and Tissue Research 322, 99-106.

Huang J-C 2008. The role of peroxisome proliferator-activated receptors in the development and physiology of gametes and preimplantation embryos. PPAR Research, doi:10.1155/2008/732303.

Humblet O, Birnbaum L, Rimm E, Mittleman MA and Hauser R 2008. Dioxins and cardiovascular disease mortality. Environmental Health Perspectives 116, 1443-1448.

Hunt PA, Koehler KE, Susiarjo M, Hodges CA, Ilagan A, Voigt RC, Thomas S, Thomas BF and Hassold TJ 2003. Bisphenol A exposure causes meiotic aneuploidy in the female mouse. Current Biology 13, 546-553.

Hussein HS and Brasel JM 2001. Toxicity, metabolism and impact of mycotoxins on humans and animals. Toxicology 167, 101-134.

Hutchison GR, Scott HM, Walker M, McKinnell C, Mahood IK, Ferrara D and Sharpe RM 2008. Sertoli cell development and function in an animal model of testicular dysgenesis syndrome. Biology of Reproduction 78, 352-360.

Hutt KJ, Shi Z, Albertini DF and Petroff BK 2008. The environmental toxicant 2,3,7,8-tetrachlorodibenzo-p-dioxin disrupts morphogenesis of the rat preimplantation embryo. BMC Developmental Biology 8, 1, doi:10.1186/1471213X-8-1.

Institute for Environment and Health (IEH) 1999. IEH assessment on the ecological significance of endocrine disruption: effects on reproductive function and consequences for natural populations (assessment A4). MRC Institute for Environment and Health, Leicester, UK.

Inoue T, Kaibara M, Sakurai-Yamashita Y, Kawano M, Ishimaru T and Taniyama K 2004. Increases in serum nitrite and nitrate of a few-fold adversely affect the outcome of pregnancy in rats. Journal of Pharmacological Sciences 95, 228-233.
IPCS 2002. Global Assessment of the State-of-the-Science of Endocrine Disruptors (ed. T Damstra, S Barlow, A Bergman, R Kavlock and G Van Der Kraak), from http://ehp.niehs.nih.gov/who/preface.pdf

Jekat FW, Meisel ML, Eckard R and Winterhoff H 1994. Effects of pentachlorophenol (PCP) on the pituitary and thyroidal hormone regulation in the rat. Toxicology Letters 71, 9-25.

Katoh K, Matsuda A, Ishigami A, Yonekura S, Ishiwata H, Chen C and Obara Y 2004. Suppressing effects of bisphenol $A$ on the secretory function of ovine anterior pituitary cells. Cell Biology International 28, 463-469.

Kelly KE 1995. Health effects of hazardous waste incineration - more of the rest of the story. In Proceedings of the International Incineration Conference, 8-12 May 1995, Seattle, WA. Retrieved 19 March 2010 from http://www.deltatoxicology.com/pdf/5cases.pdf

Kietz S and Fischer B 2003. Polychlorinated biphenyls affect gene expression in the rabbit preimplantation embryo. Molecular Reproduction and Development 64, 251-260

Kirigaya A, Hayashi S, Iguchi T and Sato T 2006. Developmental effects of ethinylestradiol on reproductive organs of female mice. In Vivo 20,867-873.

Korrick SA and Bellinger DG 2007. Persistent organic pollutants and childhood learning and behavioural disorders. Journal of Epidemiology and Community Health 61, 564-565.

Kortenkamp A 2007. Ten years of mixing cocktails: a review of combination effects of endocrine-disrupting chemicals. Environmental Health Perspectives 115, 98-105.

Krogenaes AK, Tauboll E, Stien A, Oskam IC, Lyche JL, Dahl E, Thomassen RF, Sweeney T and Ropstad E 2008. Valproate affects reproductive endocrine function, testis diameter and some semen variables in non-epileptic adolescent goat bucks. Theriogenology 70, 15-26.

Lanphear BP, Hornung R, Khoury J, Yolton K, Baghurst P, Bellinger DC, Canfield RL, Dietrich KN, Bornschein R, Greene T, Rothenberg SJ, Needleman HL, Schnaas L, Wasserman G, Graziano J and Roberts R 2005. Low level environmental lead exposure and children's intellectual function: an international pooled analysis. Environmental Health Perspectives 113, 894-899.

Li E 2002. Chromatin modification and epigenetic reprogramming in mammalian development. Nature Reviews Genetics 3, 662-673.

Li B, Liu HY, Dai LJ, Lu JC, Yang ZM and Huang L 2006. The early embryo loss caused by 2,3,7,8-tetrachlorodibenzo-p-dioxin may be related to the accumulation of this compound in the uterus. Reproductive Toxicology 21, 301-306.

Lind PM, Milnes MR, Lundberg R, Bermudez D, Orberg J and Guillette LJ 2004a. Abnormal bone composition in female juvenile American alligators from a pesticide-polluted lake (Lake Apopka, Florida). Environmental Health Perspectives 112, 359-362.

Lind PM, Orberg J, Edlund U-B, Sjoblom L and Lind L 2004b. The dioxin-like pollutant PCB $126\left(3,3^{\prime}, 4,4^{\prime}, 5\right.$-pentachlorobiphenyl) affects risk factors for cardiovascular disease in female rats. Toxicology Letters 150, 293-299.

Lind PM, Gustavsson M, Hermsen S, Larsson S, Kyle CE, Örberg J and Rhind SM 2009. Exposure to sewage sludge disrupts bone tissue homeostasis in sheep. Science of the Total Environment 407, 2200-2208.

Lovekamp-Swan T and Davis BJ 2003. Mechanisms of phthalate ester toxicity in the female reproductive system. Environmental Health Perspectives 111, 139-145.

Lundberg R, Lyche JL, Ropstad E, Aleksandersen M, Ronn M, Skaare JU, Larsson S, Örberg J and Lind PM 2006. Perinatal exposure to PCB 153, but not $P C B$ 126, alters bone tissue composition in female goat offspring. Toxicology 228, 33-40.

Lundberg R, Fox GA, Wejheden C, Lind L, Larsson S, Örberg J and Lind PM 2008. Altered bone properties in herring gulls (Larus Argentatus) residing in the Great Lakes in the early 1990s. Journal of Toxicology and Environmental Health, Part A 71, 1-9.

Lyche JL, Oskam IC, Skaare JU, Reksen O, Sweeney T, Dahl E, Farstad W and Ropstad E 2004. Effects of gestational and lactational exposure to low doses of PCBs 126 and 153 on anterior pituitary and gonadal hormones and on puberty in female goats. Reproductive Toxicology 19, 87-95.

Makrigiannakis A, Minas V, Kalantaridou SN and Chrousos GP 2006. Hormonal and cytokine regulation of early implantation. Trends in Endocrinology and Metabolism 17, 178-185.

Mandon-Pepin B, Loup B, Poumerol E, Fowler PA, Amezaga MR, Sharpe RM, Evans NP, Bellingham M, Rhind SM and Cotinot C 2009. Consequences of in utero exposure to environmental chemicals on ovary development in sheep. 
Rhind et al.

In Poster presented at the 5th Copenhagen Workshop on Endocrine Disruptors, 20-22 May, 2009, Copenhagen, Denmark, 1 pp.

Martineau D, Lagace A, Beland P, Higgins R, Armstrong D and Shugart LR 1988. Pathology of stranded beluga whales (Dephinapterus leucas) from the St. Lawrence estuary, Quebec, Canada. Journal of Comparative Pathology 98, 287-311.

McMillan BJ and Bradfield CA 2007. The aryl hydrocarbon receptor sans xenobiotics: endogenous function in genetic model systems. Molecular Pharmacology 72, 487-498.

McNatty KP, Heath DA, Lundy T, Fidler AE, Quirke L, O'Connell A, Smith P, Groome N and Tisdall DJ 1999. Control of early ovarian follicular development. Journal of Reproduction and Fertility Supplement 54, 3-16.

Meador JP, McCaarty LS, Escher BI and Adams WJ 2008. The tissue-residue approach for toxicity assessment: concepts, issues, applications, and recommendations. Journal of Environmental Monitoring 10, 1486-1498.

Meharg AA, Deacon C, Edwards KJ, Donaldson M, Davidson DA, Spring C, Scrimgeour CM, Feldmann J and Rabb A 2006. Ancient manuring practices pollute arable soils at St Kilda World Heritage Site, Scottish North Atlantic. Chemosphere 64, 1818-1828.

Meijer GAL, de Bree JA, Wagenaar JA and Spoelstra SF 1999. Sewerage overflows put production and fertility of dairy cows at risk. Journal of Environmental Quality 28, 1381-1383.

Minervini F, Dell'Aquila ME, Maritato F, Minoia P and Visconti A 2001. Toxic effects of the mycotoxin zearalenone and its derivatives on in vitro maturation of bovine oocytes and 17 -estradiol levels in mural granulosa cell cultures. Toxicology In Vitro 15, 489-495.

Moral R, Wang R, Russo IH, Lamartiniere CA, Pereira J and Russo J 2008. Effect of prenatal exposure to the endocrine disruptor bisphenol $A$ on mammary gland morphology and gene expression signature. Journal of Endocrinology 196, 101-112. Morgan HD, Santos F, Green K, Dean W and Reik W 2005. Epigenetic reprogramming in mammals. Human Molecular Genetics 14, R47-R58.

Nakanishi T 2008. Endocrine disruption induced by organotin compounds; organotins function as a powerful agonist for nuclear receptors rather than an aromatase inhibitor. The Journal of Toxicological Sciences 33, 269-276.

Nandi S, Gupta PS, Selvaraju S, Roy SC and Ravindra JP 2010. Effects of exposure to heavy metals on viability, maturation, fertilization, and embryonic development of buffalo (Bubalus bubalis) oocytes in vitro. Archives of Environmental Contamination and Toxicology 58, 194-204.

Navarrete Santos A, Ramin N, Tonack S and Fischer B 2008. Cell lineage-specific signalling of insulin and insulin like growth factor (IGF) 1 in rabbit blastocysts. Endocrinology 149, 515-524.

Navarrete Santos A, Tonack S, Kirstein M, Kietz S and Fischer B 2004a. Two insulin-responsive glucose transporter isoforms and the insulin receptor are developmentally expressed in rabbit preimplantation embryos. Reproduction $128,503-516$

Navarrete Santos A, Tonack S, Kirstein M, Pantaleon M, Kaye P and Fischer B 2004b. Insulin acts via MAPK phosphorylation in rabbit blastocysts. Reproduction 128, 517-526.

Nebert DW 2005. Inter-individual susceptibility to environmental toxicants - a current assessment. Toxicology and Applied Pharmacology 207, S34-S42.

Nikaido Y, Yoshizawa K, Danbara N, Tsujita-Kyutoku M, Yuri T, Uehara N and Tsubura A 2004. Effects of maternal xenoestrogen exposure on development of the reproductive tract and mammary gland in female CD-1 mouse offspring. Reproductive Toxicology 18, 803-811.

Nimrod AC and Benson WH 1996. Environmental estrogenic effects of alkylphenol ethoxylates. Critical Reviews in Toxicology 26, 335-364.

Nordstrom Joensen U, Skakkebaek NE and Jorgensen N 2009. Is there a problem with male reproduction? Nature Clinical Practice - Endocrinology and Metabolism 5, 144-145.

Norstrom RJ 2002. Understanding bioaccumulation of POPs in food webs: chemical, biological, ecological and environmental considerations. Environmental Science and Pollution Research 9, 300-303.

Office for National Statistics 2008. Cancer Statistics registrations: Registrations of cancer diagnosed in 2005, England. Series MB1 no. 36. National Statistics, London, UK.

Ohtake F, Fujii-Kuriyama $Y$ and Shigeaki K 2009. AhR acts as an E3 ubiquitin ligase to modulate steroid receptor functions. Biochemical Pharmacology 77 , 474-484.
Oskam IC, Lyche JL, Krogenaes A, Thomassen R, Skaare JU, Wiger R, Dahl E, Sweeney T, Stien A and Ropstad E 2005. Effects of long-term maternal exposure to low doses of PCB126 and PCB153 on the reproductive system and related hormones of young male goats. Reproduction 130, 731-742.

Paul C, Rhind SM, Kyle CE, Scott H, McKinnell C and Sharpe RM 2005. Cellular and hormonal disruption of fetal testis development in sheep reared on pasture treated with sewage sludge. Environmental Health Perspectives 113, 1580-1587.

Payne J, Rajapakse N, Wilkins M and Kortenkamp A 2000. Prediction and assessment of the effects of four xenoestrogens. Environmental Health Perspectives 108, 983-987.

Pocar P, Augustin R and Fischer B 2004. Constitutive expression of CYP1A1 in bovine cumulus oocyte-complexes in vitro: mechanisms and biological implications. Endocrinology 145, 1594-1601.

Pocar P, Augustin R, Gandolfi F and Fischer B 2003. Toxic effects of in vitro exposure to p-tert-octylphenol on bovine oocyte maturation and developmental competence. Biology of Reproduction 69, 462-468.

Pocar P, Fischer B, Klonisch T and Hombach-Klonisch S 2005a. Molecular interactions of the aryl hydrocarbon receptor and its biological and toxicological relevance for reproduction. Reproduction 129, 379-389.

Pocar P, Brevini TA, Perazzoli F, Cillo F, Modina S and Gandolfi F 2001b. Cellular and molecular mechanisms mediating the effects of polychlorinated biphenyls on oocyte developmental competence in cattle. Molecular Reproduction and Development 60, 535-541.

Pocar P, Perazzoli F, Luciano AM and Gandolfi F 2001a. In vitro reproductive toxicity of polychlorinated biphenyls: effects on oocyte maturation and developmental competence in cattle. Molecular Reproduction and Development 58, 411-416.

Pocar P, Nestler D, Risch M and Fischer B 2005b. Apoptosis in bovine cumulusoocyte complexes after exposure to polychlorinated biphenyl mixtures during in vitro maturation. Reproduction 130, 857-868.

Rajapakse N, Silva E and Kortenkamp A 2002. Combining xenoestrogens at levels below individual no-observed-effect concentrations dramatically enhances steroid hormone action. Environmental Health Perspectives 110 917-921.

Rhind SM 2002. Endocrine disrupting compounds and farm animals: their properties, actions and routes of exposure. Domestic Animal Endocrinology 23, 179-187.

Rhind SM 2005. Are endocrine disrupting compounds a threat to farm animal health, welfare and productivity? Reproduction in Domestic Animals 40, 282-290.

Rhind SM 2008. Endocrine disruptors and other food contaminating environmental pollutants as risk factors in animal reproduction. Reproduction in Domestic Animals 43(suppl. 2), 15-22.

Rhind SM 2009. Anthropogenic pollutants - a threat to ecosystem sustainability and our survival? Philosophical Transactions of the Royal Society of London 364, 3391-3401.

Rhind SM, Rae MT and Brooks AN 2001. Effects of nutrition and environmental factors on the fetal programming of the reproductive axis. Reproduction 122 , 205-214.

Rhind SM, Kyle CE, Telfer G, Duff El and Smith A 2005a. Alkyl phenols and diethylhexyl phthalate in tissues of sheep grazing pastures fertilised with sewage sludge or inorganic fertilizer. Environmental Health Perspectives 113 447-453.

Rhind SM, Kyle CE and Owen J 2005b. Accumulation of potentially toxic metals in the liver tissue of sheep grazed on sewage sludge-treated pastures. Animal Science 81, 107-113.

Rhind SM, Kyle CK, Mackie C and Telfer G 2007. Effects of exposure of ewes to sewage sludge-treated pasture on phthalate and alkyl phenol concentrations in their milk. The Science of the Total Environment 383, 70-80.

Rhind SM, Kyle CE, Mackie C and Telfer G 2009. PCB and PBDE accumulation in adult and fetal sheep grazing sludge treated pastures. Journal of Environmental Monitoring 11, 1469-1476.

Robinson J 2006. Prenatal programming of the female reproductive neuroendocrine system by androgens. Reproduction 132, 539-547.

Rider CV, Wilson VS, Howdeshell KL, Hotchkiss AK, Furr JR, Lambright CR and Gray LE Jr 2009. Cumulative effects of in utero administration of mixtures of "antiandrogens" on male rat reproductive development. Toxicologic Pathology 37, 100-113. 
Rüsse I 1983. Oogenesis in cattle and sheep. Bibliotheca Anatomica 24, 77-92. Safe SH 1990. Polychlorinated biphenyls (CBs), dibenzo-p-dioxins (PCDDs), dibenzofurans (PCDFs), and related compounds : environmental and mechanistic considerations which support the development of toxic equivalency factors (TEFs). Critical Reviews in Toxicology 21, 51-88.

Santillo D and Johnston P 2006. Effect thresholds and 'adequate control of risks. The fatal flaws in the EU Council's position on authorisation within REACH. Environmental Science and Pollution Research 13, 425-431.

Savabieasfahani M, Kannan K, Astapova O, Evans NP and Padmanabhan V 2006. Developmental programming: differential effects of prenatal exposure to bisphenolA or methoxychlor on reproductive function. Endocrinology 147, 5956-5966.

Sawyer HR, Smith P, Heath DA, Juengel JL, Wakefield SJ and McNatty KP 2002. Formation of ovarian follicles during fetal development in sheep. Biology of Reproduction 66, 1134-1150.

Scott HM, Hutchison GR, Jobling MS, McKinnell C, Drake AJ and Sharpe RM 2008. Relationship between androgen action in the 'male programming window', fetal Sertoli cell number and adult testis size in the rat. Endocrinology $149,5280-5287$.

Scott HM, Hutchison GR, Mahood IK, Hallmark N, Welsh M, de Gendt K, Verhoeven G, O'Shaughnessy PJ and Sharpe RM 2007. Role of androgens in fetal testis development and dysgenesis. Endocrinology 148, 2027-2036.

Setchell BP 1997. Sperm counts in semen of farm animals 1932-1995. International Journal of Andrology 20, 209-214.

Sharpe RM 1994. Regulation of spermatogenesis. In The Physiology of Reproduction (ed. E Knobil and JD Neill), 2nd edition, pp. 1363-1434. Raven Press, New York.

Sharpe RM and Skakkebaek NE 2003. Male reproductive disorders and the role of endocrine disruption: advances in understanding and identification of areas for future research. Pure and Applied Chemistry 75, 2023-2038.

Shi ZD and Barrell GK 1992. Requirement of thyroid function for the expression of seasonal reproductive and related changes in red deer (Cervus elaphus) stags. Journal of Reproduction and Fertility 94, 251-259.

Sikka SC and Naz RK 1999. Endocrine disruptors and male fertility. In Endocrine disruptors. Effects on male and female reproductive systems (ed. RK Naz ), pp. 225-246. CRC Press, London, UK.

Sinclair KD, Allegrucci C, Singh R, Gardner DS, Sebastian S, Bispham J, Thurston A, Huntley JF, Rees WD, Maloney CA, Lea RG, Craigon J, McEvoy TG and Young LE 2007. DNA methylation, insulin resistance, and blood pressure in offspring determined by maternal periconceptional B vitamin and methionine status. Proceedings of the National Academy of Sciences of the United States of America 104, 19351-19356.

Skakkebaek NE, Rajpert-De Meyts E and Main KM 2001. Testicular dysgenesis syndrome: an increasingly common developmental disorder with environmental aspects. Human Reproduction 16, 972-978.

Skene SA, Dewhurst IC and Greenberg M 1989. Polychlorinated dibenzo$p$-dioxins and polychlorinated dibenzofurans: the risk to human health. A review. Human Toxicology 8, 173-203.

Skinner MK 2005. Regulation of primordial follicle assembly and development. Human Reproduction Update 11, 461-471.

Smith SR 1995. Organic pollutants. In Agricultural recycling of sewage sludge and the environment (ed. SR Smith), Chapter 10, pp. 207-236. CAB International Publishing, Wallingford, UK.

Spurgeon DJ, Hopkin SP and Jones DT 1994. The effects of cadmium, copper, lead and zinc on growth, reproduction and survival of the earthworm Eisenia fetida (Savigny): assessing the environmental impact of point-source metal contamination in terrestrial ecosytems. Environmental Pollution 84A, 123-130.

Stahlhut RW, van Wijngaarden E, Dye TD, Cook S and Swan SH 2007. Concentrations of urinary phthalate metabolites are associated with increased waist cicumference and insulin resistance in adult US males. Environmental Health Perspectives 115, 876-882.

Steinberg RM, Walker DM, Juenger TE, Woller MJ and Gore AC 2008. Effects of perinatal polychlorinated biphenyls on adult female rat reproduction: development, reproductive physiology, and second generation effects. Biology of Reproduction 78, 1091-1101.
Sugiyama S, Shimada N, Miyoshi H and Yamauchi K 2005. Detection of thyroid system-disrupting chemicals using in vitro and in vivo screening assays in Xenopus laevis. Toxicological Sciences 88, 367-374.

Suk WA, Olden K and Yang RSH 2002. Chemical mixtures research: significance and future perspectives. Environmental Health Perspectives 110(suppl. 6), 891-892.

Swan SH, Elkin EP and Fenster L 2000. The question of declining sperm density revisited: an analysis of 101 studies published 1934-1996. Environmental Health Perspectives 108, 961-966.

Swanson RL, Bortman U, O'Connor P and Stanford HM 2004. Science, policy and the management of sewage materials. The New York City experience. Marine Pollution Bulletin 49, 679-687.

Swedenborg E, Ruegg J, Makela S and Pongratz I 2009. Endocrine disruptive chemicals: mechanisms of action and involvement in metabolic disorders. Journal of Molecular Endocrinology 43, 1-10.

Sweeney T, Fox J, Robertson L, Kelly G, Duffy P, Lonergan P, O'Doherty J, Roche JF and Evans NP 2007. Postnatal exposure to octylphenol decreases semen quality in the adult ram. Theriogenology 67, 1068-1075.

Sweeney T, Nicol L, Roche JF and Brooks AN 2000. Maternal exposure to octylphenol suppresses ovine fetal follicle hormone secretion, testis size, and Sertoli cell number. Endocrinology 141, 2667-2673.

Thompson J and Bannigan J 2008. Cadmium: toxic effects on the reproductive system and the embryo. Reproductive Toxicology 25, 304-315.

Tonack S, Kind K, Thompson JG, Wobus AM, Fischer B and Navarrete Santos A 2007. Dioxin affects glucose transport via the arylhydrocarbon receptor signal cascade in pluripotent embryonic carcinoma cells. Endocrinology 148, 5902-5912.

Toppari J, Larsen JC, Christiansen P, Giwercman A, Grandjean P, Guillette $\mathrm{JJ}_{\text {, }}$ Jegou B, Jensen TK, Jouannet $P$, Keiding N, Leffers $H$, McLachlan JA, Meyer 0 , Muller J, Meyts ER, Scheike T, Sharpe RM, Sumpter J and Skakkebaek NE 1996. Male reproductive health and environmental xenoestrogens. Environmental Health Perspectives 104(suppl. 4), 741-803.

Uzumcu M and Zachow R 2007. Developmental exposure to environmental endocrine disruptors: consequences within the ovary and on female reproductive function. Reproductive Toxicology 23, 337-352.

Villard PH, Caverni S, Baanannou A, Khalil A, Martin PG, Penel C, Pineau T, Seree $E$ and Barra $Y$ 2007. PPARalpha transcriptionally induces AhR expression in Caco-2, but represses AhR pro-inflammatory effects. Biochemical and Biophysical Research Communications 364, 896-901.

Vreugdenhil HJI, Slijper FME, Mulder PGH and Weisglas-Kuperus N 2002. Effects of perinatal exposure to $\mathrm{PCBs}$ and dioxins on play behavior in Dutch children at school age. Environmental Health Perspectives 110, A593-A598.

Welsh M, Saunders PTK, Fisken M, Scott HM, Hutchison GR, Smith LB and Sharpe RM 2008. Identification in rats of a programming window for reproductive tract masculinization, disruption of which leads to hypospadias and cryptorchidism. Journal of Clinical Investigation 118, 1479-1490.

Wild SR and Jones KC 1992. Organic chemicals entering agricultural soils in sewage sludges: screening for their potential to transfer to crop plants and livestock. The Science of the Total Environment 119, 85-119.

Wójtowicz AK, Augustowska K and Gregoraszczuk EL 2007. The short- and long-term effects of two isomers of DDT and their metabolite DDE on hormone secretion and survival of human choriocarcinoma JEG-3 cells. Pharmacological Reports 59, 224-232.

Wood RI and Foster DL 1998. Sexual differentiation of neuroendocrine function in sheep. Reviews of Reproduction 3, 130-140.

Wright C, Evans ACO, Evans NP, Duffy P, Fox J, Boland MP, Roche JF and Sweeney T 2002. Effect of maternal exposure to the environmental estrogen, octyl phenol, during fetal and/or postnatal life on onset of puberty, endocrine status, and ovarian follicular dynamics in ewe lambs. Biology of Reproduction 67, 1734-1740.

Yunker MB, Macdonald RW, Vingarzan R, Mitchell RH, Goyette D and Sylvestre S 2002. PAHs in the Fraser River basin: a critical appraisal of PAH ratios as indicators of PAH source and composition. Organic Geochemistry 33, 489-515. 